\title{
The Relationship between Agricultural Teaching Approaches and Food Security in Kenya
}

\author{
Hellen Joseph Njura $\mathbb{D}^{1}{ }^{1}$ Kaberia Isaac Kubai, ${ }^{2}$ Simon Thuranira Taaliu, ${ }^{3}$ \\ and Kakai Shem Khakame ${ }^{4}$ \\ ${ }^{1}$ Department of Education, University of Embu, P.O. Box 6-60100, Embu, Kenya \\ ${ }^{2}$ Department of Humanities, University of Embu, P.O. Box 6-60100, Embu, Kenya \\ ${ }^{3}$ Department of Education, Meru University of Science and Technology, P.O. Box 972-60200, Meru, Kenya \\ ${ }^{4}$ Department of Agricultural Resource Management, University of Embu, P.O. Box 6-60100, Embu, Kenya
}

Correspondence should be addressed to Hellen Joseph Njura; hellenanjurah@yahoo.com

Received 4 April 2020; Revised 27 May 2020; Accepted 28 May 2020; Published 11 July 2020

Academic Editor: Christos Troussas

Copyright (C) 2020 Hellen Joseph Njura et al. This is an open access article distributed under the Creative Commons Attribution License, which permits unrestricted use, distribution, and reproduction in any medium, provided the original work is properly cited.

\begin{abstract}
The continued food insecurity, despite the teaching of agriculture amidst the novel coronavirus (Covid-19), is a major global concern especially in Africa. There is food shortage in Africa and Kenya in particular despite the teaching of agriculture as a major subject in secondary schools. Many youth who have graduated from Kenyan secondary schools cannot adequately employ the agricultural skills developed during and after school for food security. The teaching approaches employed in secondary school agriculture should be able to develop skills of students on the aspects of food production, its accessibility, food safety, and nutrition as well as production economics. Towards this direction, this paper investigates the relationship between the agricultural teaching approaches employed in secondary schools and food security in Kenya. The study adopted descriptive survey design where data were collected using an Agriculture Teachers' Interview Schedule, a Students' Focus Group Discussion Guide, and a Parent's Questionnaire and were then analyzed using descriptive and inferential statistics. The research findings established that the lecture method, class discussions, class projects, problem solving, and tours and field trips were the common methods in agriculture classes. Though recommended in the literature review section, digital learning was hardly mentioned as a teaching approach for this study. A major conclusion for this study is that there is statistically insignificant relationship between the teaching approaches and food security. There are other factors not in the scope of this study that could be affecting food security and can be tackled at secondary school level. This paper makes a contribution to the growing body of knowledge by highlighting research gaps worth investigation on the relationship between the agricultural teaching approaches and food security that were beyond the scope of the study.
\end{abstract}

\section{Introduction}

Food security has been the main challenge in Kenya and entire sub-Saharan countries. In Kenya, it is not clear whether it is a production deficit or a kind of social dysfunction in the country. Many definitions have been suggested, but the most agreed is when people have physical, social, and economic access to sufficient, safe, and nutritious food that meets their dietary needs and food preferences for an active and healthy life at all times [1-3]. The four pillars of food security are its availability, accessibility, utilization, and stability [2]. Derived from the four pillars are the aspects of food security which are its production, physical and economic accessibility, safety, nutrition, and constancy in supply [1]. The application of the agricultural teaching approaches should therefore focus on development of skills on aspects of food production, its accessibility, food safety, and nutrition as well as production economics to help stabilize food security in the country.

Agricultural teaching approaches have been operationally defined in this study to refer to the processes or methods of attending to agriculture students' needs, experiences, and feelings both theoretically and practically and making appropriate interventions to help them develop relevant skills 
for food security. The commonly used methods of teaching in secondary schools in Kenya are the lecture method, class discussions, demonstration, class experiments, problem solving, and tours and field trips [5-8]. However, with the emergence of technological advancement, digital learning is on the rise especially in higher education [9]. This study advocates for the incorporation of digital learning especially with the negative effects of the novel coronavirus (Covid-19) in all other teaching approaches in secondary education where it is hardly found especially in developing countries. The relationship between the agricultural teaching approaches and food security is hence operationally defined in this study to refer to the association between agricultural teaching pedagogies and food security.

Empowering youths with skills has an educational relevance which could open doors to economically and socially rewarding jobs, help the development of small informalsector businesses, and support the transition from school to work for school dropouts and graduates and hence the ability to secure food both at individual and community level $[10,11]$. Applied education subjects such as agriculture are the centerpiece of the practical aspects of the secondary school curriculum [6]. Agriculture should therefore be in a position to develop skills among students that promote avenues for food security through the application of relevant teaching approaches.

The relevant agricultural teaching approaches have an implication of achieving the United [12] initiative which outlines the first Millennium Development Goal (MDG) of eradicating extreme poverty and hunger, the 2030 Agenda for Sustainable Development, the Africa's Agenda 2063 themed "the Africa We Want," and Kenya's national policies on food security with the aspects of food security in mind to alleviate the problem of food insecurity.

Various researchers have however identified many barriers for the achievement of food security. Environmental degradation which includes soil erosion devastates productive lands leading to low crop yield [13]. Deforestation and increased demand of firewood for cooking have led to high denudation of soil cover resulting in reduced food supplies [14]. These two factors have a negative effect on both the production and physical and economic access to food.

Biotic factors such as incidence of diseases, pests, and parasites have contributed enormously to the decline in food production and its safety directly affecting food security [14]. Environmental shocks such as climate change, flooding, and drought have greatly affected the consistence in food supply and hence its stability particularly in the developing countries [1].

Wars and civil unrest associated with mass refugees' movement have led to abandonment of farming activities affecting food production [13]. Health factors such as human immunodeficiency virus/acquired immunodeficiency syndrome (HIV/AIDS) and the novel coronavirus (Covid-19) have an impact on lack of the ability for farm work, food processing, and food marketing which has led to loss of trained workforce in agricultural occupation [14]. These factors are also witnessed in Kenya and their implications on food shortage may be lowered if relevant approaches are employed in teaching agriculture for skills development at the secondary school level.

The consequences of food insecurity are enormous; a situation where an individual cannot afford the basic three meals a day can be traumatic and devastating. Rollback problems of food insecurity among the people such as stealing in order to get money for food and prostitution where people resort to indiscriminate sexual intercourse for money and food follow $[13,15]$. Malnutrition due to insufficient food results in high rate of mortality in the society and lowers life expectancy [13].

Secondary school agricultural knowledge broadens the students' capacity and makes them more effective, self-reliant, resourceful, and capable of solving farming problems even at their youthful stage $[13,16]$. The current study emphasizes that the knowledge can significantly improve their agricultural productivity and guarantee food security for the family if the developed skills are appropriately transferred into the real field.

The Kenyan government, through the Ministry of Agriculture, in consultation with the County Governments and development partners has made deliberate efforts for sustainable youth participation in the agricultural sector. This is through the development of the Kenya Youth Agribusiness Strategy to address challenges that hinder youth from participating effectively in the sector [17]. The strategy is aimed at providing new opportunities for the youth in agriculture and its value chains [17]. The benefits of such a strategy can also be reaped through tapping the skills developed on youths in the process of learning agriculture at secondary school level. This would ensure optimal utilization of their potential in contributing to the agriculture sector goals of achieving food and nutrition security in the country.

The teaching of secondary school agriculture should be in a position to develop appropriate skills to adequately address food security in the country. Incorporating food safety standards in the syllabus will expose agriculture students to a wider scheme of food security management. For instance, the kitchen garden model can be used to promote dietary diversification using improved agricultural techniques that conserve limited resources [18]. Skills on food safety from production, preservation, preparation to its consumption can prevent contamination, parasitic infections, and toxic substances that would be injurious to human life [13]. These skills can be developed on students as guided by the CODEX food safety standards [19]. Such skills can help in safeguarding against food safety hazards like consumption of pesticide residual on vegetables and foreign bodies such as heavy metals and detergents in wastewater. The practical approaches can develop students skills as guided by the East African Food Safety Standards [20] to safeguard harvested grains like maize that form the hub of staple food in the country. For instance, skills on moisture control, vermin control in grain stores, proper aeration, and regular inspection during storage can greatly improve safety and reduce postharvest losses. Additionally, skills in agricultural planning and budgeting expose the students to 
proper farm management practices which leads to better production techniques and subsequent improved livelihoods in the society [16].

Class projects on school gardens give students an opportunity to participate in hands-on learning that teaches not only the intended subject but also responsibility, teamwork, and respect for nature as well as promote healthier eating habits and appreciate locally grown food sources [21, 22]. School gardens are therefore a practical opportunity for students to reconnect with nature and the ecology that surrounds them [22], resulting in increased food security within it.

Applied education subjects such as agriculture, home science, business studies, computer studies, art and craft, and music are the centerpiece of the practical aspects of the secondary school curriculum [6]. Among other elective subjects, agriculture is in a position to develop skills among students that promote avenues for food security. A school that has a farm can give students a chance to develop the skills geared towards food security both within the school and the surrounding community [23]. Kenya's strategies to address food insecurity are broad-based and their implementation would benefit from reliable and research-based information on the contribution of secondary school agricultural teaching approaches to food security.

In the current trends of agricultural education, various teaching approaches have been approved in the syllabus to be used in the teaching of agriculture in secondary schools. These include the lecture method, class discussions, demonstration, class experiments, problem solving, tours and field trips [5-8], and the current digital learning [9].

Many studies regarding food security have been carried out worldwide; however, there is little research evidence on the contribution of agricultural teaching approaches in secondary schools in averting the problem of food insecurity. This study attempts to address the knowledge gap by establishing the relationship between the agricultural teaching approaches and food security. It was therefore guided by one research question: what is the relationship between the agricultural teaching approaches employed in secondary schools and food security?

The study confined itself to secondary schools in Embu County in Kenya. The respondents were the agriculture teachers, their students, and the parents/guardians. There are other stakeholders involved in the teaching and learning process such as the school management who include the Board of Management (BOM), the sponsor such as the church, and the administrators such as the chiefs. This study however considered the agriculture teachers and the students who are directly involved in the learning process and the parents/guardians who are the direct beneficiaries of the skills developed. All the other stakeholders are not directly involved in the learning process. They were also likely to be represented by the targeted groups which would have caused duplication of information by the same respondents, for example, parents form both the school community and members of the church. There is a wide range of practical subjects taught in secondary schools; however, this research was limited to agriculture due to the major role it plays as a source of food compared with the others. Information about food security obtained from agriculture would be in depth than even concentrating on all the pratical subjects at a go.

\section{Literature Review}

2.1. Agricultural Teaching Approaches. Teachers in secondary schools in Kenya have been found to use various pedagogical methods at their disposal in teaching agriculture. The most common methods in agriculture classes are the lecture, class discussions, group work and questioning, demonstration, class projects, problem solving/guided discovery, and tours and field trips $[6,24]$. Digital learning has currently found its way in education as technology advances [9] especially with the novel coronavirus (Covid-19). However, this has not been well exploited in secondary education although it is the most result-oriented approach due to its appeal to adolescents [25]. Different teachers use different methods depending on the availability of facilities and resources as per the status of the institution [6]. To arrest students' attention, interest, and curiosity and promote their performance, the use of activity-stimulating and studentcentered approach like digital learning, demonstration method, class projects, and tours and field trips instead of depending on the conventional lecture approach needs to be embraced [24].

2.1.1. Lecture Method. Lectures usually take place in a classroom format. It is also referred to as talk and chalk or textbook method [26]. This method is teacher centered with little participation from learners [8]. The teacher is seen as the repository of all knowledge while the students are passive recipients of knowledge transmitted by the teachers in the learning process [8].

Properly structured lectures may be the best teaching method especially when suited to the transmission of conceptual and systematic knowledge [5]. In different studies, the major advantage of the lecture method is the ability to get a huge amount of information to a lot of people in a short amount of time $[5,8]$ although retention of the information might be a challenge [8]. In the context of the current study, this method is the least effective in developing agricultural skills for food security.

2.1.2. Discussion Method. The use of discussions as a primary teaching method in agriculture allows the teacher to stimulate critical thinking on the learners [8]. This approach also helps the teacher establish a rapport with the students, demonstrating an appreciation of their contributions and challenging them to think more deeply and to articulate their ideas more clearly. The frequent questions asked by both the teacher and the students provide a means of measuring learning and exploring in depth the key concepts of the course [7].

Through class room discussions, a set of acquired skills that is necessary for establishing and developing interpersonal relationships such as communication skills, cooperation, emotional intelligence, and critical thinking is 
developed [24, 27]. The current research advocates the incorporation of this approach to develop these skills to help students have a clear picture of the likely causes, effects, and mitigation measures of food insecurity in their homes, community, and the nation at large. Discussion can be improved through incorporation of digital technology. For instance, if a student does not feel comfortable speaking in a classroom of more than 40-50 students, they may post a "Tweet" to contribute to class discussion [28].

2.1.3. Tours and Field Trips. The usual purpose of outdoor training through tours and field trips is to develop teamwork skills [8]. Field trips to agricultural centers, industries, farmlands, etc., where students get firsthand experience and practice of the theoretical methods of agriculture, can prove to be very helpful [29]. However, assignments, write-ups, and projects must be given to students to aid them to participate effectively in the field trips [29].

Tours and field trips in secondary schools may however disorient the school time table and hence need proper timing such as during the school midbreaks and holidays. The field trip is one of the most complex and expensive activities in the educational system and hence should be planned as an integral part of the curriculum rather than as an isolated activity [30].

In the context of the current study, agriculture students can benefit from such experiences by employing the team spirit in school-based and community projects such as nursery practices and poultry projects from where they can sell the produce to both the school and the community making them food secure.

2.1.4. Demonstration Method. Through the demonstration method, the teacher does whatever the learners are expected to do at the end of the lesson by showing them how to do it and explaining the step-by-step process to them [31]. The demonstration may include diagrams, charts, e-learning, and other illustrative materials accompanied by an oral explanation [7]. The audience observes the process, listens to the explanation, and poses questions during or at the conclusion of the demonstration [7]. The demonstration method increases students' interest and understanding and consequently promotes high achievement rate [24]. Demonstration procedures in agriculture may include machine milking, how to preserve fish, how to graft a mango tree, or how to install drip irrigation in a home garden. In the context of the current study, incorporation of demonstration improves both recall and psychomotor skills when the students are allowed to repeat the same procedures either individually or in groups.

2.1.5. Class Projects. The project method is a teacher-facilitated collaborative approach in which students acquire and apply knowledge and skills to define and solve realistic problems using a process of extended inquiry [32]. Class projects are therefore student-centered, following standards, parameters, and milestones clearly identified by the teacher. The project teaching method is based on the conviction that learning by doing, discussing in groups, and revisiting ideas and experiences are superior ways of gaining a better understanding of one's environment [33]. According to existing literature, practical work though class projects makes learning more enjoyable [34-35] and their purposes in agricultural education have expanded beyond skill acquisition and proficiency to include personal development for diverse career preparation beyond agriculture [36]. The current study advocates class projects as an important part of an agricultural education that provides application of concepts taught in class. Students can hence transfer the acquired skills to their homes.

2.1.6. Problem-Solving Approach/Discovery Method/Problem-Based Learning. The problem-solving approach is a student-centered approach to teaching where students participate in the learning process by contributing problems, analyzing the factors associated with the problems, developing possible solutions to the problems, placing the solution(s) into action, and evaluating the results of the solution [37].

Problem-based learning (PBL) is a constructivist approach to instruction that revolves around a real-world illstructured problem [38]. The method promotes both the acquisition of content knowledge and the development of thinking skills and strategies. Teachers typically take on the role of the facilitator and students become responsible for information learnt. This method typically ends with a presentation of solutions and an evaluation of the process used in solving the problem. The method can also be enhanced by enriching it with digital learning. According to [39], multimedia projects allow students to explore subject matter using film, audio, and even software they create.

When incorporated into secondary school agriculture, students develop an extensive and flexible knowledge base; develop effective problem-solving strategies; develop selfdirected, lifelong learning skills; become effective collaborators; and become intrinsically motivated to learn [40]. There is agreement on the contribution of PBL to factors such as knowledge retention, student satisfaction, motivation, and critical thinking; however, there is much less agreement on the role of PBL in knowledge acquisition [40]. Studies have evidenced that PBL can help promote critical thinking skills among students and consistently display growth in problem-solving skills [41, 42]. The method has been found to be effective in promoting higher-order thinking $[40,43,44]$.

The discovery method has been found to improve student motivation and interest [45-47]. Students also indicate more satisfaction with PBL than with traditional methods of instruction [41, 43, 45, 48]. However, controversy on the use of this approach is the existence of little empirical evidence as to what students are learning and how $[37,49,50]$.

In the context of the current study, problem-solving instruction may not fit the learning style of some students since abstract learners may not recognize problems as such when presented to them. Future studies may therefore require investigating the use of constructivist problem-based approaches to determine effects on learning outcomes in agriculture classrooms. 
2.1.7. Digital Learning. Technology provides the possibility of including multimedia and interactive resources that can make adult learning more attractive and realistic, encouraging and even inspiring adults to develop their skills [51]. In reference to the youth who are the targeted future farmers, this technology can enhance their skills development and its application to the food industry.

Videos, radio, mobile phones, and television are among the information communication technology (ICT) tools that are gaining popularity in enhancing farmers' access to agricultural-related knowledge and information [52]. Due to their social learning nature, videos in particular have a high potential to stimulate social learning because they combine visual and audio elements that facilitate internalization and contextualization of knowledge or information, which enable farmers to share and learn from experiences [53, 54]. When incorporated into the classroom setting, the social learning nature of the ICT devices can fast-track skills development in agriculture and be the bait to making youths be more interested in agriculture. The utilization of mobile technologies in game-based learning improves the effectiveness of the educational process and augments students' knowledge; hence, an effective educational game design must achieve a balance between fun and educational value [55]. Additionally, the use of computers, tablets, digital cameras, video conferencing technology, and Global Positioning Systems (GPS) devices can all enhance a student's learning experience [39]. The intuitive nature of the mobile technology, their affordability compared to other ICT devices, mobility, usability, and accessibility among the youth are factors that can ease their integration in agriculture.

The current study emphasizes that the use of the digital tools especially in secondary school agriculture should not be underestimated if skills in enhancing food security have to be developed.

2.2. The Aspects of Food Security. The fundamental objective in learning agriculture is for learners to develop basic principles of agricultural production relevant to a nation and the surrounding environment [56]. Practical teaching approaches result in development of the required skills for food security. The skills developed encompass the aspects of food production, accessibility, food safety, and nutrition as well as constancy in its supply [1].

Skills in production may include infrastructure development such as water harvesting and soil and water conservation measures. The use of class projects such as rock catchments may therefore develop hands-on experiences in such activities geared towards food security. Skills in preservation and rehabilitation of the ecosystem can result in improved food accessibility both physically and economically. The teaching activities such as safe food production, preparation, and food combination at consumption level can improve both food safety and nutrition which form the utilization pillar of food security [1]. Skills in insurance against crop failure can reduce vulnerability of individuals to temporal food supply [1]. These can be well articulated in areas of farm planning and budgeting through discussions and demonstration of diversification of risks and uncertainties through mixed farming [56].

2.3. The Relationship between Agricultural Teaching Approaches and the Aspects of Food Security. The relationship between the agriculture teaching approaches and food security can be explained by their contribution to the aspects of food security based on a conceptual framework as shown in Figure 1.

The independent variables for this study were the types of teaching approaches which comprised of the lecture method, class discussions, demonstration, class projects, problem-solving method, and digital learning. The influence of the independent variables over the dependent variable may be affected by intervening variables, namely, schoolbased factors, community influence, home-based factors, political factors/governance, and the teacher's level of training. The framework was based on some of the researchers' ideas regarding the contribution of the approaches to teaching agriculture for food security as well as related literature. It is from these that more ideas were generated on the contribution of these approaches to food security. This was therefore an expansion of the already existing body of knowledge in that it puts an emphasis on the blended practical teaching approaches at the psychomotor domain of Bloom's taxonomy.

Based on the conceptual framework used in the study (Figure 1), the relationship between the agricultural teaching approaches and food security could be explained by their contribution to skills development and the contribution of the developed skills to aspects of food security.

2.3.1. Contribution of the Agricultural Teaching Approaches to Skills Development. The central aim of the agricultural education at the basic level is to train students in the basic principles of agriculture, provide avenues for the development of their skills, and change the attitudes of the young children towards agriculture. In a study on the Ghanian context, basic education in agriculture is vital because the future generation of farmers and agriculturists will need basic technical, managerial, and entrepreneurial skills to compete in the expanding agricultural economy [57]. This is not different from the Kenyan context in that when knowledge, skills, and attitudes are rationally utilized, they contribute greatly to social and economic development [58].

Skills development is key to the agricultural sector development. A skill is a well-established habit of doing things by people which entails the ability to demonstrate, act, think, and behave in specific activity in such a way that the process becomes natural to the individual through repetition or practice [59]. This is therefore equivalent to capacity building for food security. On the other hand, capacity building involves enhancing the ability of individuals, groups, organizations, and communities to sustainably meet their food and nutrition security challenges [60]. The everincreasing technological advancement and surge of unemployed graduates even after secondary school in the country have necessitated the inclusion of more technology and 


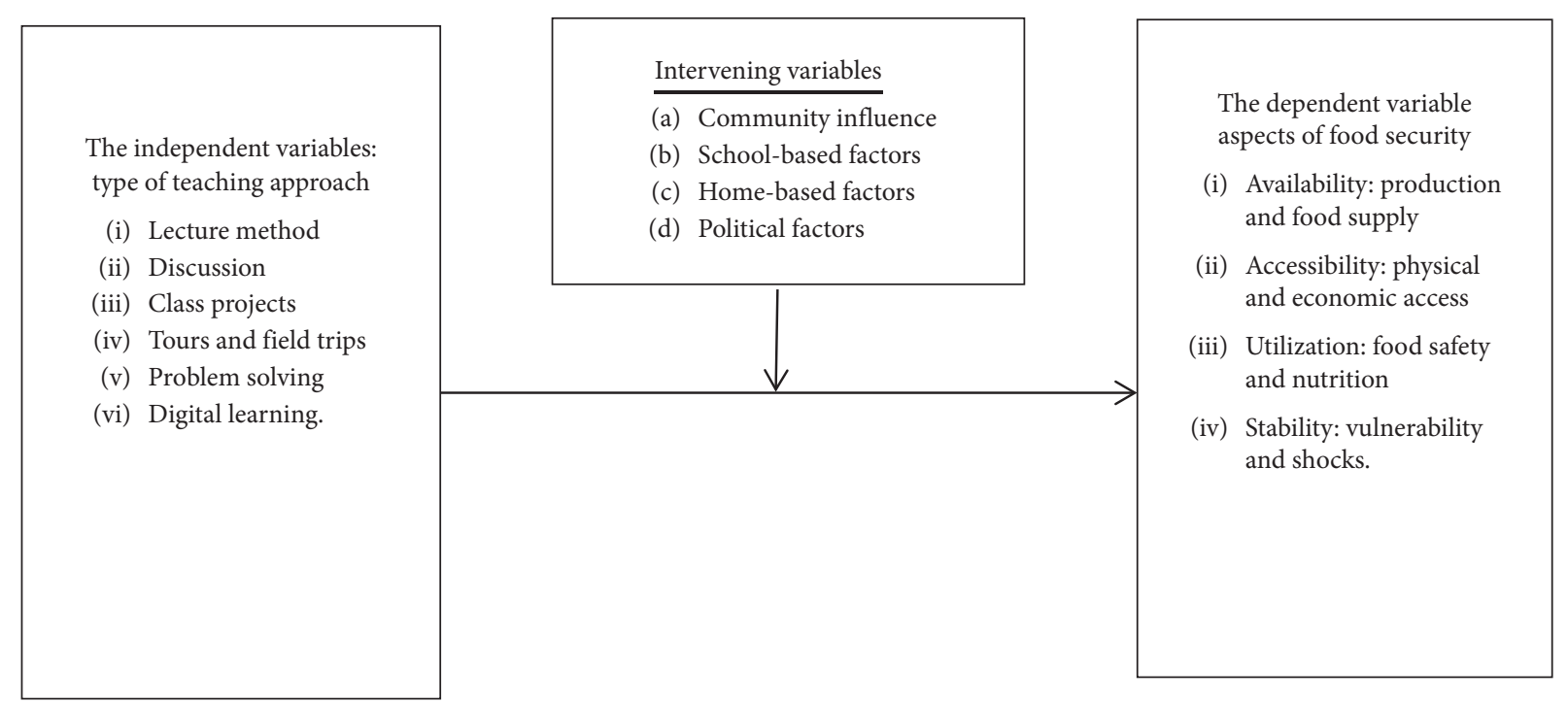

Figure 1: Relationship between the agricultural teaching approaches and aspects of food security.

vocational-oriented subjects into the school curriculum [61]. This study puts an emphasis on skills development through digital learning so as to make them more competent to the extent of becoming self-reliant to work for food production, its accessibility, safety, nutrition, and its safety in supply.

In the context of the current study, open and learnercentered pedagogy especially the teaching of agricultural aspects has a huge potential to overcome all obstacles so that a focus on teaching agriculture connects school with the everyday life of the pupils in both rural and urban areas. The study by Roberts [16] explains how secondary school agriculture knowledge broadens farmers' capacity, makes them more effective, self-reliant, resourceful, and capable of solving farming problems, and as a result significantly improves their crop productivity and hence guarantees food security for the family. Establishing the relationship between the agricultural skills developed and food security is therefore necessary.

\subsubsection{Contribution of the Agricultural Skills to Aspects of} Food Security. There are many ventures both in crop and livestock production where secondary school students can employ the skills developed in agriculture destined to food security. This is for instance skills in budding, grafting, and layering which can sustain an individual. Budded citrus is required in different compounds, homes, churches, playgrounds, schools, and hospitals among others for planting. Empowerment of youth with skills in piggery production can sustain an individual in management, control, feeding, fattening, and finishing them for marketing, distributing, and processing its products and by-product for the benefit of mankind. This can generate a lot of money to the investors.

Skills training in agriculture also includes skills in the use of farm tools to till the soil and manipulate farm machines and equipment to carry out different farming activities [13]. In schools, students learn how to grow crops using sustainable food production practices, combine theoretical and practical approaches, and are encouraged to see farming as an enterprise.

In the context of the current study, capacity building through investment in research, innovation systems, and linking researchers, extension agents, farmers, and nongovernmental organizations (NGOs) with schools are necessary so that the skills are absorbed and effectively employed in the various food production sectors. It is not only about learning skills and techniques but also about becoming empowered and frequently applying the skills so developed especially at local levels in order to use the same skills for the food industry [60].

The benefits and opportunities of linking young agriculture students to farmers through practical internships can create a closer relationship between the two [62]. This is likely to be a way of taking the knowledge learnt in class to the field. Both the farmer and the student can use such knowledge in food production subsequently combating food insecurity.

The aspects of food security are attributed to parameters such as having physical and economical access to sufficient, safe, and nutritious food that meets the dietary needs and food preferences for an active and healthy life [63]. Agricultural skills developed on the learners should enable them access food both at household and individual level. Food availability can be achieved through developing skills to enhance access to sufficient quantities of food all year round [64]. These include urban farming practices, off-season irrigation, and postharvest practices to curb food losses as well as food preservation measures.

In the context of the current study, food insecurity arises due to the inadequate skills or failure to utilize the skills when needed. Transitory food insecurity can be reduced if skills associated with timely land preparation, planting, and harvesting are developed and timely utilized. According to [64], field cultivation itself is a very seasonal activity, with differing labour requirements at different times of the year. Ground clearance, planting, weeding, and harvesting all 
make different demands on the farm household and leave varying amounts of family labour available for off-farm activity, which might or might not be food related [63]. Youths at home can utilize the agricultural skills for offseason farming when the labour demand is low, resulting in continuous food supply.

Marketing too can be seasonal while some food commodities are difficult to store and will only be available for short periods of time after the harvest. Others are available all year round because they can be stored fairly readily [64]. Agricultural skills in food processing such as drying of fruits, vegetables, and tuber crops can enhance their availability off season. When done at the household level, food production and supply will eventually have positive effects in terms of stabilizing food supplies at the community and national levels and ultimately at the national level. This is particularly true of measures aimed at improving rural infrastructure, research, storage, and food marketing such as irrigation which will reduce susceptibility to rainfall variations [64].

\section{Methodology}

3.1. Location of Study. The study was carried out in Embu County representing the forty-seven counties in Kenya in regard to resource endowment, climatic conditions, rural versus urban areas, private versus public schools, and diversity in population distribution. Such differences have an influence on the varied teaching approaches on skills development and their relationship to food security.

3.2. Research Design. The study adopted descriptive survey design applying the mixed method approach where both quantitative and qualitative data were collected in a single study. Quantitative methods ensure breadth while the qualitative method enables the researcher to have in-depth information by refining and explaining quantitative statistical results by exploring participants' views in depth [65]. Descriptive survey designs are used in preliminary and exploratory studies to allow researchers to gather information, summarize, present, and interpret data for the purpose of clarification [66]. Additionally, descriptive survey is intended to produce statistical information about aspects of education that interest policy makers and educators [67]. In the context of the current study, descriptive research design was adopted to investigate the background to the research problem: the relationship between agricultural teaching approaches and food security. Only the opinions of the respondents on the relationship between the various approaches to teaching agriculture and food security were being investigated. The answers to the research question would open room for further research as well as inform policy makers on aspects of teaching secondary school agriculture that create more hands-on skills driven towards positive contribution to food security.

3.3. Sampling Procedures and Sample Size. The study applied mixed sampling methods where both random and nonrandom sampling designs were used. Heterogeneous purposive sampling was done on the study area. The study location has varied geographical zones, i.e., arid areas, semiarid areas, highlands, resource endowment, urban areas, and rural areas from where schools with varied settings are found. The county as well provided diverse range of respondents, i.e., agriculture teachers, agriculture students, and their parents/guardians who could provide diverse opinions on the relationship between the agriculture teaching approaches and their relevance to food security. Stratified random sampling was administered to obtain the number of schools required in the public and private school categories. Systematic random sampling was further applied to get the specific schools as well as the agriculture teachers. The researchers carried out simple random sampling to get the required number of students. This was achieved by obtaining the number of students specializing in agriculture in forms three and four from their subject teachers. However, class registers from the class teachers in forms one and two were used to determine the students present. This was with the assumption that they would not have selected their subject options by the end of form two. The researchers then assigned numbers to all the students and used Microsoft excel to generate random numbers to sample the students to take part in the study. Through proportionate sampling, twelve groups of students were obtained from the public schools while eight groups were obtained from the private school category. Random sampling ensures the law of statistical regularity which states that if on average the sample chosen is a random one, the sample will have the same composition and characteristics as the universe [68]. The researchers reached the parents through issuance of questionnaires to the students to reach them as well as through scheduled school academic clinics. The sample population is presented in Table 1.

3.4. Research Instruments. An Agriculture Teachers' Interview Schedule (ATIS) containing 18 questions was developed. These were distributed into seven open-ended questions, six closed-ended questions, and five in Likert scales.

A Students' Focus Group Discussion Guide (SFGDG) was prepared with a set of open-ended questions which allowed students to speak freely and provide as much information as they knew. Two handouts labeled A and B were attached to the guide for the students to fill in during the discussion. Focus group discussions keep the interactions focused, while allowing individual perspectives and experiences to emerge [69]. The questions helped the researchers in developing themes in relation to the students' opinions on the relationship between agricultural teaching approaches and food security.

A parents' questionnaire containing seven closedended questions and three open-ended questions was developed for the parents. It is from these items that the question on the relationship between the agriculture teaching approaches on skills development and food security was answered. 
TABLE 1: Sample population.

\begin{tabular}{lcc}
\hline Subject category & Target population & Actual sample \\
\hline Public schools & 186 & 60 \\
Private schools & 12 & 8 \\
Agriculture teachers & 235 & 111 \\
Agriculture students & 46,340 & 376 \\
Parents/guardians & 46,340 & 300 \\
\hline
\end{tabular}

3.5. Pretesting the Research Instruments. The questionnaire, the interview schedule, and the focus group discussion guide were subjected to pretesting. A pretest sample of $1 \%$ and $10 \%$ depends on the sample size, which is $1 \%$ for a large sample and $10 \%$ for a small sample [70]. The researchers used $10 \%$ of the research participants to give a total of fourteen schools, two focus group discussions, eleven interview schedules, and thirty-two parents to participate in the pilot study. Pretesting was necessary to reveal weaknesses in the research tools. It is done to test whether the questions measure what they are supposed to measure, check ambiguity, and to test for researcher's bias [71]. The randomly selected schools for piloting were not included in the actual study. Piloting improved the validity of the instruments by addressing any difficulties that the respondents would have encountered especially on the clarity of the questions. The pilot data were used to compute the reliability coefficient of the instruments using the internal consistency approach.

3.6. Data Collection Procedures. A letter of introduction from the University of Embu helped the researchers obtain a research permit from the National Commission for Science, Technology and Innovation (NACOSTI). The researchers also obtained a consent letter from the County Director of Education before contacting the school principals to prepare for data collection. The research instruments were administered over a span of three months where the interviews with the agriculture teachers were conducted. Within these months, the researchers met the students in their focus group discussions as well as issuing and receiving back the parents' questionnaires through the students and the school academic clinics. Two field assistants were involved in recording the interviews and the distribution of the questionnaires.

3.7. Data Analysis. The edited data were coded and fed into the computer for analysis using the Statistical Package for Social Sciences (SPSS) version twenty-three for Windows. The researchers transcribed the audio data from face-to-face interviews and students' focus group discussions. The parents' and the agriculture teachers' responses were read and reread for proper interpretation. Descriptive statistics were used to explain the qualitative data. This was used with the question on opinions on the relationship between the agriculture teaching approaches and skills development as well as that of the relationship between the skills developed and aspects of food security. Percentages were used to show frequency of use of each teaching approach and its contribution to aspects of food security while the mean and standard deviation were used to show the relationship between the teaching approaches and aspects of food security. Inferential statistics were used to test the hypothesis that there is no statistically significant relationship between the agricultural teaching approaches and food security. A simple regression analysis was used to test the relationship between agricultural teaching approaches and food security using the regression equation of $\hat{Y}=a+b X$.

Since data obtained were normally distributed as shown in Figure 2, the parametric test was used. These were ordinal data for the contribution of the teaching approaches to skills development as well as the contribution of the skills to aspects of food security. Nominal tests were used with the question on ways of improving the teaching of agriculture in schools for food security around the community. Refer to the dataset (supplementary file (available here)) for more details.

\section{Research Results}

The researchers sought to establish the relationship between the agricultural teaching approaches employed in secondary schools and food security in Kenya. The following hypothesis was stipulated.

$H_{0}$ : there is no statistically significant relationship between the agricultural teaching approaches and food security.

$H_{1}$ : there is a statistically significant relationship between agricultural teaching approaches and food security.

4.1. Agriculture Teachers' Opinions on the Relationship between the Agricultural Teaching Approaches and Food Security. The researchers sought to find out the agriculture teachers' opinions on the contribution of the teaching approaches employed to food security. It was observed that the relationship between the agriculture teaching approaches and food security could be explained by their contribution to skills development.

4.1.1. Agriculture Teachers' Opinions on the Relationship between the Teaching Approaches and Skills Development. The researchers sought to find out the agricultural teaching approaches that developed skills for food security. Table 2 indicates teachers' views on the rate at which each teaching approach developed skills for food security.

It was observed that $56(52.3 \%)$ of the agriculture teachers positively felt that problem solving/discovery was the most important agriculture teaching approach that developed skills for food security closely followed by class projects as reported by 54 (50.9\%). A total of $58(54.2 \%)$ of the teachers had neutral perception towards contribution of discussion in developing skills for food security. It is worth noting that 61 (56.5\%) of teachers felt that lecturing was the least important teaching approach that developed skills for food security. This implies that more emphasis should be put into problem solving/discovery and class projects as they 


\begin{tabular}{|c|c|c|}
\hline $\begin{array}{c}\text { Histogram } \\
\begin{array}{c}\text { Dependent variable: aspect } \\
\text { of food security }\end{array}\end{array}$ & \multirow[b]{2}{*}{$\begin{array}{l}\text { Mean }=-5.12 E-17 \\
\text { Std. dev }=0995 \\
N=96\end{array}$} & \multirow{2}{*}{ 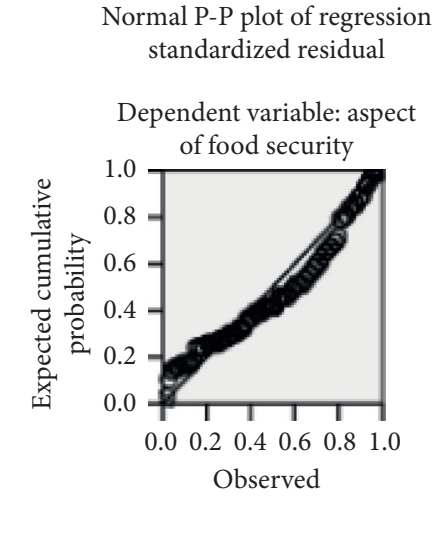 } \\
\hline $\begin{array}{c}25- \\
\text { Regression standardized } \\
\text { residual }\end{array}$ & & \\
\hline $\begin{array}{l}\text { Normality: the residuals are approxim } \\
\text { normally distributed; hence, the assun } \\
\text { was met. }\end{array}$ & tely & $\begin{array}{l}\text { Linearity: the scatterplot showed that } \\
\text { there was a strong positive linear } \\
\text { relationship between the two. }\end{array}$ \\
\hline
\end{tabular}

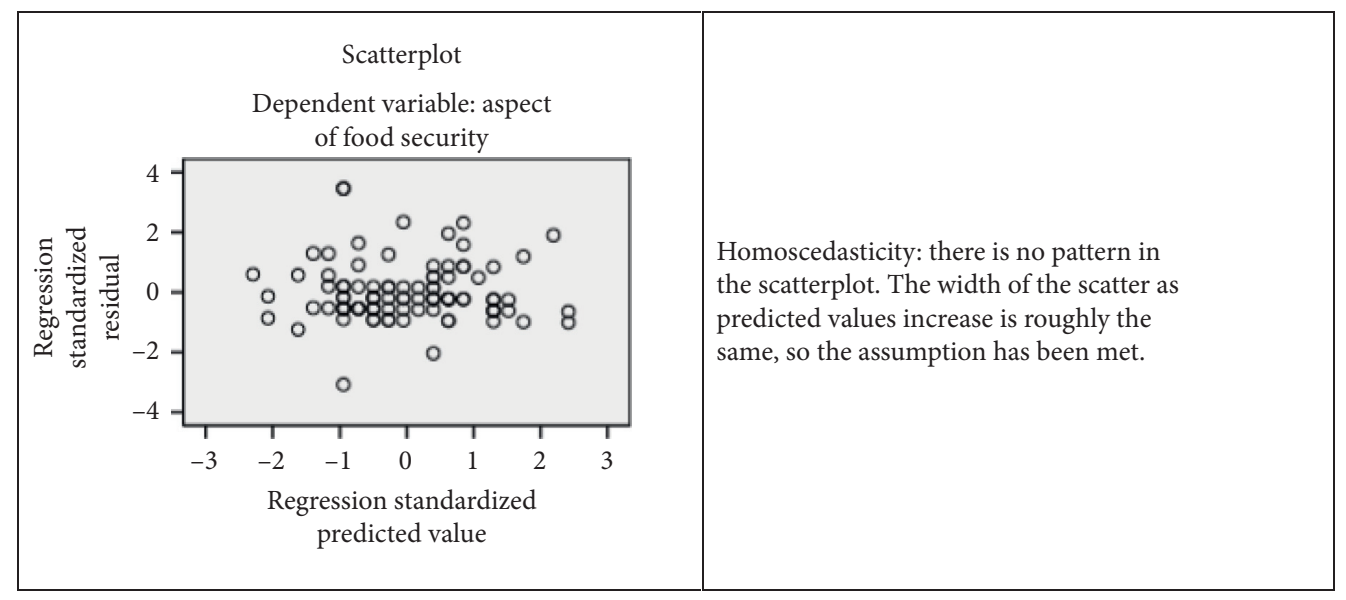

FIgURE 2: Test for normality, linearity, and homoscedasticity.

TABLE 2: Rate at which each teaching approach develops skills for food security.

\begin{tabular}{|c|c|c|c|c|c|c|}
\hline & \multicolumn{2}{|c|}{ Most important } & \multicolumn{2}{|c|}{ Important } & \multicolumn{2}{|c|}{ Least important } \\
\hline & $N$ & $\%$ & $N$ & $\%$ & $N$ & $\%$ \\
\hline Lecture & 16 & 14.8 & 31 & 28.7 & 61 & 56.5 \\
\hline Class projects & 54 & 50.9 & 36 & 34.0 & 16 & 15.1 \\
\hline Problems solving/discovery & 56 & 52.3 & 31 & 29.0 & 20 & 18.7 \\
\hline Demonstration & 50 & 46.3 & 49 & 45.4 & 9 & 8.3 \\
\hline Discussion & 40 & 37.4 & 58 & 54.2 & 9 & 8.4 \\
\hline
\end{tabular}

were seen to contribute greatly in developing skills for food security.

\subsubsection{Opinions on the Relationship between Skills Developed} and Food Security. The researchers sought to find out the relationship between the skills developed on students and food security. Both the teachers and the parents had their opinions as presented in Figure 3.

A total of 251 (96.5\%) parents reported that agricultural skills developed had resulted in increased food security within the school community with only $3.5 \%$ of them feeling otherwise. Likewise, slightly more than half $(52.5 \%)$ of the agriculture teachers reported that agricultural skills developed had resulted in increased food security within the school community with a $47.5 \%$ of them having the opinion that the skills developed had not led to increased food security. It can then be deduced that agricultural skills developed and food security had a positive relationship. Thus, the teaching of agriculture for skills development should be encouraged at secondary school level with an aim of increasing food security. The opinion that the skills developed had not translated into increased food security could be associated with constraints such as inadequate financial support for learning agricultural projects in schools, some students disliking manual work, and inadequate time for agriculture practicals and projects 


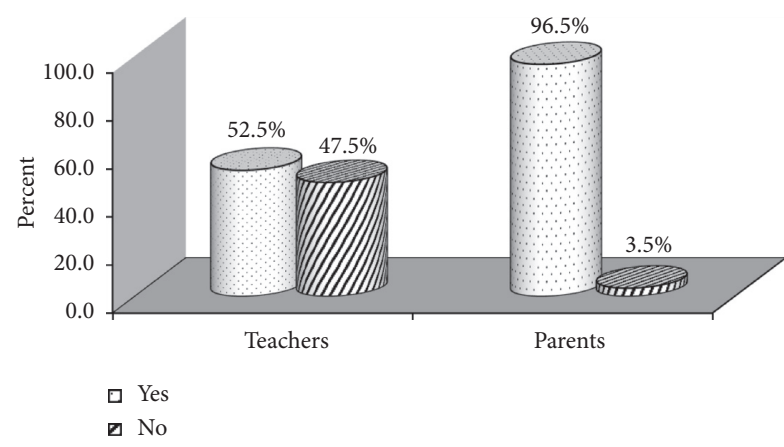

FIGURE 3: Opinions on the relationship between the agricultural skills developed and food security.

ultimately decreasing food production and hence food insecurity within the school community.

It was further observed that the relationship between the agricultural skills developed and food security could be explained by the frequency of the use of the skills for food security and their contribution to aspects of food security.

(1) Agriculture Teachers' Opinions on the Frequency of the Use of the Skills for Food Security. The researchers sought to find out the agriculture teachers' opinions on the frequency of the use of the skills developed for food security. Their responses are shown in Table 3.

As reported by most teachers, students often applied agricultural skills developed especially in nursery practices (56.6\%), irrigation $(45.6 \%)$, soil and water conservation (52.5\%), and pest and disease control (50.9\%). However, most teachers felt that students least applied agricultural skills developed in livestock production (46.2\%), e.g., poultry and rabbitry, ploughing (51.0\%), and crop propagation such as budding and grafting. The reasons could be that the pieces of land they lived on were too small for the use of machines such as ploughs, it was capital intensive or the land conditions such as hills and stones not necessitating the use of the implements.

When asked the level at which the students were very active in the use of the skills developed for food security, both the agriculture teachers and the parents had almost similar opinions as shown in Figure 4.

The study revealed that most students were very active in use of the skills developed in school while in forms three and four as reported by $29.5 \%$ of the parents and $45.5 \%$ of teachers, respectively. This could be associated with the fact that students at these levels had covered a lot of content with a variety of skills to make choices which could be employed both at school and home for food security. Students however were not very active in the use of the skills at form one probably because they were new to the school with very few agriculture topics having been covered at this level.

(2) Contribution of the Agricultural Skills to Food Security. The researchers went further to investigate the teachers' opinions on the contribution of agricultural skills developed on students to the aspects of food security. To attain the rate of contribution, the sum of all the responses was calculated with the highest being 24 and the lowest being 6 . This was then categorized into three levels: $1-8$ as low contribution, $9-16$ as average, and 17-24 as high. They are shown in Figure 5.

The responses obtained included aspects of food security such as availability of enough food for an active healthy life, food was readily available when needed, food available was nutritionally balanced in many households, the available food was safe to consumers, availability of steady supply of food for households, and economical acquisition of food by the household. $69.4 \%$ of teachers reported that agriculture skills developed on students had an average contribution towards increased food security, and $18.0 \%$ said that the contribution was high, whereas $12.6 \%$ of teachers said that agriculture skills developed on students had a low contribution towards food security.

4.2. Students' Opinions on the Relationship between the Agricultural Teaching Approaches Employed and Food Security. The researchers were interested in finding out the students' opinions on the approaches they felt that their teachers were employing with the aim of developing skills on them for food security. The information was audio recorded and then transcribed into themes for analysis.

4.2.1. School Projects. Some schools were reported to have been rearing fish, cattle, pigs, and poultry. However, as reported by the students, much work was left to the school groundsmen to manage the enterprises. This could be attributed to inadequate time allocated to cover the entire agriculture syllabus. Hence, students could not effectively participate in the management practices to acquire adequate skills for food security. Other students reported that their schools had Young Farmers' Clubs from where they could practice agriculture which developed on them basic skills for food production at household level.

Excerpt 4.1:

"Our school has tree nurseries; we only visit them at form two to learn nursery practices. It is the groundsman who manages the trees."

\section{Excerpt 4.2:}

"We rarely have class projects, the shamba is very small for this, however, the form fours carry their KCSE projects on them."

4.2.2. Tours and Field Trips. Further some students reported that their schools had sometimes allowed them to attend shows and incorporated field trips in teaching agriculture. A good number of students reported that their schools sometimes gave time for exploration and outside learning.

Excerpt 4.3:

"Sometimes we are taken out on field trips, around the school and to the neighbouring counties. We have learnt machine milking, silage preparation. ...I believe these skills are good enough for application after school." 
TABle 3: Agriculture teachers' opinions on the frequency of the use of the skills developed for food security.

\begin{tabular}{|c|c|c|c|c|c|c|}
\hline & \multicolumn{2}{|c|}{ Most often } & \multicolumn{2}{|c|}{ Often } & \multicolumn{2}{|c|}{ Least often } \\
\hline & $N$ & $\%$ & $N$ & $\%$ & $N$ & $\%$ \\
\hline Nursery practices & 22 & 20.8 & 60 & 56.6 & 24 & 22.6 \\
\hline Ploughing & 8 & 7.7 & 43 & 41.3 & 53 & 51.0 \\
\hline Irrigation & 15 & 14.6 & 47 & 45.6 & 41 & 39.8 \\
\hline Soil and water conservation & 22 & 21.0 & 55 & 52.4 & 28 & 26.7 \\
\hline Livestock production, e.g., poultry and rabbitry & 19 & 17.9 & 38 & 35.8 & 49 & 46.2 \\
\hline Pest and disease control & 16 & 15.1 & 54 & 50.9 & 36 & 34.0 \\
\hline Crop propagation such as budding and grafting & 13 & 12.3 & 34 & 32.1 & 59 & 55.7 \\
\hline
\end{tabular}

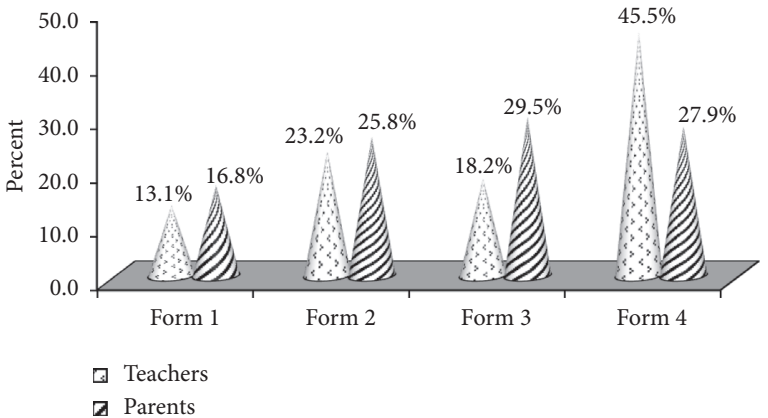

FIGURE 4: Level at which the students were very active in use of the agricultural skills developed.

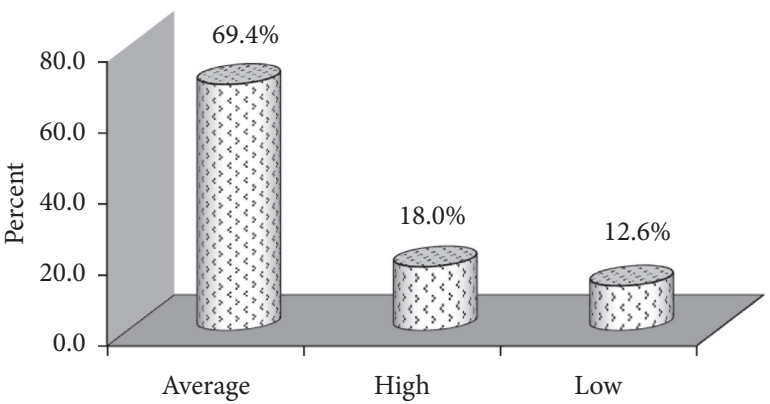

FIGURE 5: Contribution of agriculture skills developed on food security.

\section{Excerpt 4.4:}

"Agriculture students in our school go for tours at form three and form four. Our teacher told us by then we shall have covered a good number of topics."

4.2.3. Demonstration Method. Some students reported that their teachers used demonstration method. However, the research findings for this study revealed that such demonstrations were mainly carried out by facilitators during field trip and tours. In this regard, students who were not taken out on field trips had no demonstration going on. Those that had demonstrations in school had a few livestock, farm tools, and equipment as well as an operational school farm.

Excerpt 4.5:

"Our school has a fenced demonstration garden from where we practice nursery practices. It also has a traditional model granary from where we learn postharvest practices at form two."

Excerpt 4.6:

"My school has a greenhouse; we grow vegetables through irrigation in them. We were also shown how to pinch them. A farming system I intend to do after school if I'll have capital."

4.2.4. Discussion Method. A number of students in their groups mentioned that their agriculture teachers gave them discussion questions which developed their theoretical approach to answering questions related to food security. In addition, participation in agriculture symposiums gave them opportunities to interact and blend ideas learnt by students from other schools not only for the examination but also to observe progress in their school farms.

4.3. Students' Opinions on Specific Approaches That May Help Them Develop More Skills for Food Security. The researchers further sought to find out from the students the approaches that needed to be incorporated in learning for them to develop more skills for food security. Students were individually asked to highlight the most preferred approaches from a handout labeled $B$.

Three themes were generated from this question related to internship programmes, invitation of technical experts, and increased practical sessions. The suggestions are presented in Table 4.

Table 4 indicates multiple responses from students for a question on approaches that may help them develop more agricultural skills for food security.

4.3.1. Attendance of Internship Programmes. A total of 158 (42.0\%) students recorded attendance of internship as the most critical approach. They felt that students should be attending internships for two weeks in an agricultural-based institution to give them the required exposure and experience of the real world. This would not only prepare them for jobs in future but also help them continually develop skills for food security while in school; this would be equivalent to on-the-job training. 
TABLE 4: Students' views on specific approaches that may help them develop more skills for food security.

\begin{tabular}{|c|c|c|}
\hline Approach & $N$ & $\%$ \\
\hline Students should be attending internships for around two weeks in an agricultural-based institution & 158 & 42.0 \\
\hline Greater commitment involving technical experts from agricultural institutions & 129 & 34.2 \\
\hline Increased instructional sessions through creation of adequate time for practical aimed at food security & 89 & 23.8 \\
\hline$N$ & 376 & 100.0 \\
\hline
\end{tabular}

4.3.2. Invitation of Technical Experts. A total of 129 (34.2\%) students felt that greater commitment in involving technical experts from agricultural institutions was necessary in schools as this would in turn add more and new skills to the students.

Excerpt 4.7:

"We need technical experts to come and demonstrate practices such as grafting, budding and hoof trimming. We may not afford to pay for tours and field trips all the time hence some miss out in such practices."

\section{Excerpt 4.8:}

"Neighbouring schools can also team up; coordinate with field officers to explain technical points during field days."

4.3.3. Increased Practical Sessions. Finally, 89 (23.8\%) of the students listed increased instructional sessions through creation of adequate time for practical agriculture as the third critical approach for success in agriculture aimed at food security. In agreement with the teachers' views is the opinion that more time was needed for practical sessions and in-depth learning. Majority of the work covered theoretically in lectures and giving notes would hence translate into problem solving and class projects paving way for more skills development for food security in secondary schools.

Excerpt 4.9:

"I think we need to have practical sessions on the school timetables inform of double sessions. We also need to have a well-equipped agriculture laboratory. We do not need to wait until we are in form four to carry out agriculture projects."

4.4. Parents' Opinions on the Relationship between the Agricultural Teaching Approaches and Food Security. The researchers sought to find out the parents' opinions on the contribution of the teaching approaches employed to food security. It was observed that the relationship between the agriculture teaching approaches and food security could be explained by their experiences from the contribution of agricultural skills developed in their children in secondary schools to aspects of food security. Parents were first asked to rate the experiences from the agricultural skills developed in their children in secondary schools. Their responses are recorded in Table 5 .

A total of $236(78.7 \%)$ parents rated improved food production at home as the most important experience they had witnessed from their children who had done agriculture in secondary schools. This implies that students were applying the agriculture skills developed in school at home. This was followed closely by personal growth as reported by $230(76.4 \%)$ of parents. This could be associated with the livelihood earned from the homebased projects or even the passion for farming after learning agriculture. A total of 181 (59.7\%) parents rated career preparation as a most important success for their children in agriculture.

The deduction from this experience is that agriculture helped students to gain skills that would in future offer career opportunity for them either in employment, e.g., in a farm or self-employment. A total of 181 (61.1\%) parents also felt that through success in agriculture, their children could undertake house-based income-generating projects, thus adding to food security in their families. Further, a total of $132(44.1 \%)$ parents felt that hands-on training and community service learning were also very important aspects developed from learning agriculture. However, a total of 105 (35.4\%) of the parents felt that room for travel was only least important in relation to their children's success in agriculture.

The study further sought to find out whether parents would make their children choose agriculture as an elective subject as they joined form three. The proportion of their responses is shown in Figure 6.

A vast proportion $(90.7 \%)$ of the parents reported that they would make their children choose agriculture as an elective subject with only $9.3 \%$ saying that they would not. This implies that most parents had embraced agriculture as an important subject.

The parents were further asked in an open-ended question to give the reasons why they would make their children choose agriculture as an elective subject as regards to food security. The largest proportion of the parents mentioned that they would prefer their children to do agriculture as an elective subject because they would earn income from it, gain soil coservation skills, develop careers for national development, acquire knowledge and skills for food production and security, come up with new skills needed for farming, and develop skills for personal growth and finally because agriculture is the backbone of the Kenyan economy. However, one parent reported that he would not want his children to choose agriculture as an elective subject because it was time consuming with a lot of manual work. This has the implication that some parents had an influence on their children's' subject selection or their children selected the subject without informed decision on the expectations. 
TABLE 5: Parents' experiences from agricultural skills developed in their children in secondary schools.

\begin{tabular}{lccccc}
\hline \multirow{2}{*}{ Experience from agricultural skills } & \multicolumn{2}{c}{ Most important } & \multicolumn{2}{c}{ Important } & \multicolumn{2}{c}{ Least important } \\
& $N$ & $\%$ & $N$ & $\%$ & $N$ \\
\hline Improved food production at home & 236 & 78.7 & 46 & 15.3 & 18 \\
Personal growth & 230 & 76.4 & 55 & 18.3 & 16 \\
Career preparation & 181 & 59.7 & 91 & 30.0 & 3.0 \\
House-based income-generation projects & 181 & 61.1 & 80 & 27.0 & 35 \\
Hands-on training & 133 & 45.4 & 91 & 31.1 & 10.2 \\
Community service learning & 132 & 44.1 & 99 & 33.1 & 11.8 \\
Room for travel & 88 & 29.6 & 104 & 35.0 & 68 \\
\hline
\end{tabular}

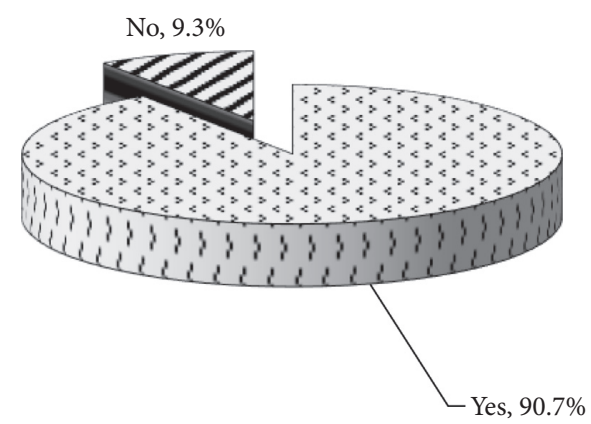

Figure 6: Percentage proportion of the parents' opinions for their children to do agriculture as an elective subject.

TABLE 6: Parents' opinions on the frequency of the use of the skills developed for food security.

\begin{tabular}{|c|c|c|c|c|c|c|}
\hline \multirow{2}{*}{ Practice } & \multicolumn{2}{|c|}{ Most often } & \multicolumn{2}{|c|}{ Often } & \multicolumn{2}{|c|}{ Least often } \\
\hline & $n$ & $\%$ & $n$ & $\%$ & $n$ & $\%$ \\
\hline Nursery practices & 121 & 41.0 & 107 & 36.3 & 67 & 22.7 \\
\hline Ploughing & 145 & 49.5 & 79 & 27.0 & 69 & 23.5 \\
\hline Irrigation & 117 & 40.5 & 85 & 29.4 & 87 & 30.1 \\
\hline Soil and water conservation & 152 & 51.5 & 94 & 31.9 & 49 & 16.6 \\
\hline Livestock production, e.g., poultry and rabbitry & 168 & 56.2 & 85 & 28.4 & 46 & 15.4 \\
\hline Pest and disease control & 145 & 48.8 & 86 & 29.0 & 66 & 22.0 \\
\hline Crop propagation such as budding and grafting & 121 & 41.0 & 107 & 36.3 & 67 & 22.7 \\
\hline
\end{tabular}

When asked to rate how often their children applied the skills developed in school for food security, parents had their opinions against the listed farming practices as shown in Table 6.

A total of 168 (56.2\%) parents reported that their children most often applied skills developed in livestock production such as poultry and rabbitry while 152 (51.5\%) applied in soil and water conservation. These two practices require basic skills that can be practiced by a form two student; hence, it is likely to be frequently carried out. It was also observed that children often applied the skills developed in nursery practices $(41.0 \%)$, ploughing $(49.5 \%)$, irrigation (40.5\%), and in pest and disease control (48.8\%). The three practices may be capital intensive for the parents; however, when established, students could participate. This indicates that most students were applying the agriculture skills developed in their homes which in turn resulted in improved food security. Finally, it is worth noting that crop propagation such as budding and grafting was least applied by students in their homes. These practices require experts who may not have been available during the teaching of such a topic. This implies that technical experts were either sometimes or never invited to the schools to teach agriculture lessons.

4.5. Regression Analysis Tests on the Relationship between Agricultural Skills Developed and Food Security. Before carrying out simple regression analysis to test the relationship between agricultural skills developed and food security, the researchers first checked the assumption of these data.

4.5.1. Tests for Independence/Autocorrelation. One of the assumptions of regression is that the observations are independent. If observations are made over time, it is likely that successive observations are related. If there is no autocorrelation (where subsequent observations are related), the Durbin-Watson statistic should be between 1.5 and 2.5. The Durbin-Watson statistic (1.42) was slightly below 1.5 which indicates that there was an insignificant autocorrelation. 
TABle 7: Mean and standard deviation.

\begin{tabular}{lccc}
\hline Descriptive statistics & Mean & Std. deviation & $N$ \\
\hline Aspect of food security & 14.56 & 2.741 & 96 \\
Teaching approaches for skills development & 24.77 & 4.46 & 96 \\
\hline
\end{tabular}

TABLE 8: Model summary of the relationship between the agricultural teaching approaches and food security.

\begin{tabular}{lcccc}
\hline Model & $R$ & $R$ square & Adjusted $R$ square & Std. error of the estimate \\
\hline 1 & $.033^{\mathrm{a}}$ & .001 & -.010 & 2.754 \\
\hline${ }^{\mathrm{a}}$ Predictors: (constant), teaching approaches for skills development (lecture, discussion, class projects, tours and field trips, problem solving, and digital \\
learning). ${ }^{\mathrm{b}}$ Dependent variable: food security (availability, accessibility, utilization, and stability). $N=96 ; R=0.033 ; R 2=0.001$, and an adjusted square of \\
-010.
\end{tabular}

TABle 9: Analysis of variance (ANOVA) results for agricultural teaching approaches and food security.

\begin{tabular}{lcccccc}
\hline Model & & Sum of squares & Df & Mean square & $F$ & Sig. \\
\hline 1 & Regression & 8.181 & 1 & 8.181 & $.299^{\mathrm{b}}$ \\
& Residual & 711.324 & 95 & 7.488 & \\
& Total & 719.505 & 96 & & \\
\hline
\end{tabular}

${ }^{\mathrm{a}}$ Dependent variable: food security (availability, accessibility, utilization, and stability). ${ }^{\mathrm{b}}$ Predictors: (constant), teaching approaches: lecture, discussion, class projects, tours and field trips, problem solving, and digital learning. $N=96, F(1,95)=1.093$, and $p$ value $=0.299>0.05$.

TABle 10: Regression model to determine the degree of dependence of food security on the teaching approaches.

\begin{tabular}{|c|c|c|c|c|c|c|c|c|}
\hline \multirow[t]{2}{*}{ Mode } & & \multicolumn{2}{|c|}{$\begin{array}{l}\text { Unstandardized } \\
\text { coefficients }\end{array}$} & \multirow{2}{*}{$\begin{array}{c}\text { Standardized coefficients } \\
\text { Beta }\end{array}$} & \multirow[t]{2}{*}{$T$} & \multirow[t]{2}{*}{ Sig. } & \multicolumn{2}{|c|}{ Collinearity statistics } \\
\hline & & $B$ & Std. error & & & & Tolerance & VIF \\
\hline \multirow[t]{2}{*}{1} & Constant & 16.10 & 1.474 & & 10.923 & .000 & & \\
\hline & Teaching approaches & -.167 & .160 & .107 & -1.045 & .299 & 1.000 & 1.000 \\
\hline
\end{tabular}

${ }^{\mathrm{a}}$ Dependent variable: food security.

4.5.2. Test for Multicollinearity. Multicollinearity is an unacceptably high level of intercorrelation among the independents, such that the effects of the independents cannot be separated. Under multicollinearity, estimates were unbiased but assessments of the relative strength of the explanatory variables and their joint effect were unreliable. Since the variance inflation factor $\mathrm{VIF}=1.0<5.0$, we conclude that multicollinearity was not a problem.

The statistics in Table 7 show the mean and standard deviation of our dependent and independent variables. The mean for aspect of food security was 14.56 with a standard deviation of 2.74 for a total $N$ of 96 while that of teaching approaches for skills development was 24.77 with standard deviation of 4.46 for a total $\mathrm{N}$ of 96 . The strength of the relationship between the dependent and the independent variables is shown in Table 8.

The results of the model summary revealed that only $0.1 \%$ of food security could be explained by approaches used for teaching agriculture for skills development. This implies that food security could be affected by other factors other than approaches used in teaching agriculture for skills development. To test the significance of the model, an analysis of variance was carried out as shown in Table 9.

Analysis of variance summary was used to test the significance of the model. Since $F(1,95)=1.093$ and $p$ value $=0.299>0.05$, we conclude that there was a statistically insignificant relationship between the teaching approaches employed for development of skills and food security. Food security is a function of availability, accessibility, utilization, and stability [2]. The relationship of these functions with the teaching approaches illustrates whether food security is dependent on these teaching approaches. In order to determine the degree of dependence of food security on the teaching approaches, a regression coefficient was established as shown in Table 10.

Results of the regression coefficient revealed that there was a negative and statistically insignificant relationship between the agricultural teaching approaches and food security. A unit decrease in application of the teaching approaches decreased food security by $-0.167,(l \beta=-0.167$, $t=-1.045$, and $p$ value $=0.299)$. In reference to the regression formula used, $\hat{Y}=a+b X$, where $\hat{Y}$ is food security, " $a$ " is agricultural teaching approaches at 16.10 , and $X$ is a unit increase in teaching approaches which is -0.167 , the equation for this study will be $\hat{Y}=16.10+(-0.167) b$, where " $b$ " is all other factors held constant.

The study established that holding all other possible factors that influence food security constant, a unit decrease in approaches to teaching agriculture would lead to a -0.167 decrease in food security. This implies that teaching approaches employed for skill development did not significantly affect food security. 


\section{Discussion}

The study findings show that the relationship between the agriculture teaching approaches and food security can be explained by their contribution to skills development and the contribution of these skills to the aspects of food security. The results of this study are in tandem with those of [5-8], indicating that the commonly used methods in agriculture classes are the lecture method and class discussions which have little contribution to skills development for food security. The other recorded methods that were rarely applied in learning agriculture are class projects, tours and field trips, and problem-solving/discovery method. Despite the fact that the review of literature indicated that digital learning through the use of devices like computers, mobile technology, and videos is a technological teaching approach, it was not mentioned as a teaching method that was being incorporated in learning agriculture. This leaves a research gap on the role of the media technology in secondary school agriculture for enhancing food security. The integration of digital learning mainly focused on higher education. This leaves another gap recommending for further research on the extent to which digital learning as a pedagogy has been integrated into teaching secondary school agriculture. This is because the related literature indicates that the mobile technology is a friendly support tool for teachers to develop their classes and generate an environment of interaction, cooperation, and collaboration between them and the learners [25]. The integration of the social media-based learning tools in the curriculum such as mobile learning can help the teachers to design the instructional system according to the changing needs of learners or society at large such as the food security agenda $[9,25,51]$.

In order to answer the research question, it was established that there was an insignificant relationship between the agricultural teaching approaches employed in secondary schools and food security. This indicates that there could be other factors not in the scope of this study that could be affecting food security and can still be tackled at secondary school level. The issues of changing climate, drought, flooding, and other extreme weather events affect the farmers' production and harvesting of crops or animals [1]. The authors advocate that even though these factors cannot be matched with the approaches to teaching agriculture as was done with the regression analysis test, they are useful in providing relevant information to education policy makers. Therefore, teaching about them at secondary school level and their mitigation measures should not be underestimated. For instance, they can affect other important variables that impact on availability, accessibility, utilization, and stability of food for individuals, households, and communities at national and international levels. Climate shock for example can affect all the four dimensions of food security: food availability, food accessibility, food utilization, and food system stability [59]. The teaching of agriculture should therefore focus on developing skills that encompass the aspects of food security. The contribution of the agricultural skills to the aforementioned aspects of food security however cannot be successfully achieved if constraints such as overloaded school curriculum, inadequate teaching, and learning support materials are not first adequately dealt with. In [44], DFID recommends the need to incorporate agricultural and environmental experiences which can be used as a way of making basic education in rural areas more relevant to the local situation.

\section{Conclusion}

The objective of this study was to establish the relationship between agricultural teaching approaches and food security. To this direction, thorough research on the relevant literature has been conducted and an evaluation of the relationship between the agricultural teaching approaches and food security was done. This has been based on the contribution of the teaching approaches to skills development and further the contribution of these skills to aspects of food security. These entail the aspects of food production, its accessibility, food safety, and nutrition as well as production economics. These can ultimately help to meet the four pillars of food security, namely, its availability, accessibility, utilization, and stability, and hence reduce poverty and finally achieve economic development in any country. Based on the conceptual framework that was adopted for this study (Figure 1), the identified teaching approaches are the lecture method, class discussions, class projects, problem solving, and tours and field trips. Though highly recommended in the literature section, digital learning was not mentioned as a teaching approach used in agriculture classes for this study.

In reference to the regression analysis, the study concludes that there was a negative and a statistically insignificant relationship between the agricultural teaching approaches and food security. In this case, other factors not in the scope of this study may have a major influence on skills development and their contribution to food security. More so, probably the methods employed were not in line with the required skills for food security, for instance a lot of lecture/theory than class projects as revealed in the responses. The teaching is more examination oriented than competence based as demanded by the competence-based curriculum, and therefore there is little food security agenda in the teaching process.

\section{Limitation}

The limitation of this study was that the relationship between digital learning as a pedagogy in agriculture classes and food security could not be established. Though highly discussed in the literature section as a great step for innovative learning, its role in contributing to skills development for food security could not be explained in this particular study. The future plans are therefore to find out the relationship between digital learning in secondary school agriculture and food security.

\section{Direction for Further Research}

The authors recommend further investigations on

(1) The most appropriate skills to target when teaching agriculture for secondary schools with the aim of 
guiding the agriculture teachers on how to link schools to the community in enhancing food security in the country.

(2) The role of the media technology in secondary school agriculture for enhancing food security.

(3) The extent to which digital learning as pedagogy has been integrated into teaching secondary school agriculture.

\section{Data Availability}

The dataset is available as a supplementary file in a zip folder.

\section{Ethical Approval}

After obtaining a research permit from the National Commission for Science, Technology and Innovation (NACOSTI), the researchers obtained a consent letter from the office of the County Director of Education (Embu) which was presented to the school principals to allow for data collection from the agriculture teachers and their students. The students assented to participate in the study while the school principals consented on behalf of the parents and guardians because the study involved students who were under 18 years of age. A copy of the consent letter was also attached to the parent's questionnaire. Respondents participated in the study on a voluntary basis and they could withdraw at will.

\section{Conflicts of Interest}

The authors declare that they have no conflicts of interest.

\section{Acknowledgments}

The authors wish to acknowledge the immense support from the two supervisors and other experts from the University of Embu. They also acknowledge the office of the County Director of Education, Embu County, and those of the Principals in secondary schools in the county for allowing data collection. Furthermore, the authors acknowledge the agriculture teachers, the students, and the parents/guardians who participated in the interviews, focus group discussions, and filling in of the questionnaires, respectively.

\section{Supplementary Materials}

This section contains two documents. The first one contains scanned document entailing the letter of Introduction for Hellen Njura Joseph from University of Embu, research authorization from NACOSTI scanned with the research permit, authorization from the Embu County Commissioner's office, and that of the office of the County Director of Education, Embu. The second file is that of the dataset generated during the study using SPSS version 23 . The entire study was on the "Approaches to Teaching Agriculture for Food security: a case of Secondary Schools in Embu County, Kenya" which was guided by four objectives, namely, (1) to identify the agricultural teaching approaches employed in secondary schools; (2) to determine the effect of the agricultural teaching approaches on skills development for food security; (3) to establish the relationship between the agricultural teaching approaches and food security; and (4) to find out the constraints faced in teaching secondary school agriculture for food security. This article was guided by objective 3 as outlined above. (Supplementary Materials)

\section{References}

[1] FAO, An Introduction to the Basic Concepts of Food Security Information for Action, Food and Agriculture Organization, Rome, Italy, 2008.

[2] World Food Programme, 2019-Global Report on Food Crises, World Food Programme, Rome, Italy, 2019.

[3] World Health Organization, The State of Food Security and Nutrition in the World 2018, WHO, Geneva, Switzerland, 2018.

[4] World Bank, The World Bank Annual Report 2008, World Bank, Washington, DC, USA, 2008.

[5] B. G. Charlton, "Lectures are such an effective teaching method because they exploit evolved human psychology to improve learning," Medical Hypotheses, vol. 67, no. 6, pp. 1261-1265, 2006.

[6] P. Munyao, The Impact of the Smasse Inservice Training on the Performance of Chemistry in the Kenya Certificate of Secondary Education (KCSE) in Secondary Schools in Kangundo Sub-County Machakos County, University of Nairobi, Nairobi, Kenya, 2014.

[7] E. K. Saina, N. J. Kathuri, P. K. Rono, M. J. Kipsat, and T. Sulo, Food Security in Kenya: The Impact of Building Rural Farmers' Capacity through Agricultural Education in Secondary School, Department of Agricultural Economics and Resource Management, University of Nairobi, Nairobi, Kenya, 2012, http:// www.afma.ke.org.

[8] C. Troussas, A. Krouska, and C. Sgouropoulou, "Collaboration and fuzzy-modeled personalization for mobile gamebased learning in higher education," Computers \& Education, vol. 144, Article ID 103698, 2020.

[9] R. Toplis and M. Allen, "I do and I understand? Practical work and laboratory use in United Kingdom Schools. Eurasia," Journal of Mathematics, Science and Technology Education, vol. 8, no. 1, pp. 3-9, 2012.

[10] S. C. Ayonmike, "Skill training in Nigerian technical colleges: benefits and challenges," Journal of Qualitative Education, vol. 6, no. 1, pp. 75-86, 2010.

[11] F. Umar, Lecture method of teaching, definition, advantages \& disadvantages, 2012, http://studylecturenotes.com/lecturemethod-of-teaching-definition-advantages-disadvantages.

[12] UNFAO, The State of Food Insecurity in the World, FAO, Rome, Italy, 2008.

[13] K. Mwiria, Vocationalization of Secondary Education: Kenya Case Study, Researchgate, Berlin, Germany, 2002, https:// www.researchgate.net/topic/publication.

[14] FAO, Rome Declaration on World Food Security and World Food Summit Plan of Action, FAO, Rome, Italy, 1996.

[15] D. T. Vernon and R. L. Blake, "Does problem-based learning work? A meta-analysis of evaluative research," Academic Medicine, vol. 68, no. 7, pp. 550-563, 1992.

[16] B. N. Roberts, "Contextualizing personality psychology," Journal of Personality, vol. 75, no. 6, pp. 1071-1082, 2007. 
[17] MoALF, Kenya Youth Agribusiness Strategy 2017-2021, Positioning the Youth at the Forefront of Agricultural Growth and Transformation, Government Printer, Nairobi, Kenya, 2017.

[18] Global Communities, Food Security \& Agriculture, Global Communities, Silver Spring, MD, USA, 2018.

[19] CODEX, International Food Standards, FAO, Rome, Italy, 2019, http://www.fao.org/fao-who-codexalimentarius/aboutcodex/en/ \#c453328.

[20] EAC, Quality Infrastructure in the East African Community, EAC, Arusha, Tanzania, 2015, http://www.eac-quality.net/ the_sqmt-community/news-events.htmI?txmin/news.

[21] A. Bucklin-Sporer and R. K. Pringle, How to Grow a School Garden: A Complete Guide for Parents and Teachers, Timber Press, Portland, OR, USA, 2010.

[22] J. Osborne and S. Collins, "Pupils' views of the role and value of the science curriculum: a focus-group study," International Journal of Science Education, vol. 23, no. 5, pp. 441-467, 2001.

[23] J. U. Ndem and D. Ph, "Agriculture at the secondary school level," vol. 9, no. 3, pp. 1-7, 2013.

[24] N. E. Daluba, "Effect of demonstration method of teaching on students' achievement in agricultural science," World Journal of Education, vol. 3, no. 6, pp. 1-7, 2013, https:// educationaltechnology.net/problem-based-learning-pbl/.

[25] S. Kurt, "Problem-based learning (PBL)," in Educational Technology, 2020.

[26] S. P. T. Gbamanja, Essentials of Curriculum and Instruction: Theory and Practice, Pam Unique Publishers, Port-Harcourt, Nigeria, 1991.

[27] O. C. Falode, I. A. Adewale, S. C. Ilobeneke, M. E. Falode, and A. O. Robinson, "Effects of discussion instructional strategy on achievement and retention of secondary school students in human geography in Minna, Nigeria," Journal of Scientific and Engineering Research, vol. 2, no. 4, pp. 78-84, 2015.

[28] Jessy and Charu, "Using social media for educational purposes: approaches and challenges," in Proceedings of the 2015 International Educational Conference 2015 Learning Technologies in Education at Jamia Millia Islamia, New Delhi, India, 2015.

[29] Adom, Contemporary Techniques or Innovations in Teaching Agricultural Science at Secondary School Level, Kwame Nkrumah University of Science and Technology, Kumasi, Ghana, 2017.

[30] O. W. Olowa, "Effects of the problem solving and subject matter approaches on the problem solving ability of secondary school agricultural education," Journal of Industrial Teacher Education, vol. 46, no. 1, 2009.

[31] I. E. Ameh, B. P. Daniel, and Y. Akus, Research and Methods in the Social Sciences, Rowis Press, Ankpa, Nigeria, 2007.

[32] R. T. Howell, "The importance of the project method in technology education," Journal of Industrial Teacher Education, vol. 40, no. 3, 2003.

[33] A. I. Diise, H. Zakaria, and A. A. Mohammed, "Effectiveness of project method of teaching on agricultural knowledge and skills acquisition among agricultural science students of Awe Senior High School in the Upper East Region, Ghana," World Journal of Educational Research and Reviews, vol. 4, no. 1, pp. 62-75, 2018.

[34] E. W. Jenkins and N. W. Nelson, "Important but not for me: students' attitudes towards secondary school science in England," Research in Science \& Technological Education, vol. 23, no. 1, pp. 41-57, 2005.

[35] J. A. Orodho, Techniques of Writing Research Proposal and Reports in Education and Social Sciences, NRB: Bureau of
Educational Researchers, Kenyatta University, Nairobi, Kenya, 2003.

[36] Resilient Educator, Three innovative methods of teaching for high school educators, https://resilienteducator.com/classroomresources/3-innovative-methods-of-teaching, 2020.

[37] G. R. Norman and H. G. Schmidt, "The psychological basis of problem-based learning," Academic Medicine, vol. 67, no. 9, pp. 557-565, 1992.

[38] S. Burris and B. L. Garton, Problem-Based Learning in Secondary Agriculture Classroom: Effect on Critical Thinking and Content Knowledge, Researchgate, Berlin, Germany, 2006, https://www.researchgate.net/.

[39] E. J. Ozer, "The effects of school gardens on students and schools: conceptualization and considerations for maximizing healthy development," Health Education \& Behavior, vol. 34, no. 6, pp. 846-863, 2010.

[40] P. Van Mele, J. Wanvoeke, and E. Zossou, "Enhancing rural learning, linkages, and institutions: the rice videos in Africa," Development in Practice, vol. 20, no. 3, pp. 414-421, 2010.

[41] A. Ball and N. Knobloch, "An exploration of the outcomes of utilizing ill-structured problems in pre-service teacher preparation," Journal of Agricultural Education, vol. 45, no. 2, pp. 62-71, 2004.

[42] C. E. Hmelo, "Problem-based learning: effects on the early acquisition of cognitive skill in medicine," Journal of the Learning Sciences, vol. 7, no. 2, pp. 173-208, 1998.

[43] K. S. Cockrell, J. A. H. Caplow, and J. F. Donaldson, "A context for learning: collaborative groups in the problembased learning environment," The Review of Higher Education, vol. 23, no. 3, pp. 347-363, 2000.

[44] R. F. Dods, "An action research study of the effectiveness of problem-based learning in promoting the acquisition and retention of knowledge," Journal for the Education of the Gifted, vol. 20, no. 4, pp. 423-437, 1997.

[45] R. R. Gordon, A. M. Rogers, M. Comfort, N. Gavula, and B. P. Mcgee, "A taste of problem-based learning increases achievement in urban minority middle-school students," Educational Horizons, vol. 79, no. 4, pp. 171-175, 2001.

[46] J. M. Herman and N. A. Knobloch, "Exploring the effects of constructivist teaching on students' attitudes and performance," in Proceedings from the 2nd Annual North Central Region, Lafayette, IN, USA, 2004.

[47] H. J. Njura, I. K. Kaberia, and S. T. Taaliu, "Effect of agricultural teaching approaches on skills development for food security: a case of secondary schools in Embu County, Kenya," The Journal of Agricultural Education and Extension, vol. 26, no. 3, pp. 239-252, 2019.

[48] M. A. Albanese and S. Mitchell, "Problem-based learning," Academic Medicine, vol. 68, no. 1, pp. 52-81, 1993.

[49] C. E. Hmelo-Silver, "Problem-based learning: what and how do students learn?" Educational Psychology Review, vol. 16, no. 3, pp. 235-266, 2004.

[50] J. E. Dyer and E. Osborne, "Effects of student learning style on short and long-term retention of subject matter using various teaching approaches," Journal of Agricultural Education, vol. 40 , no. 40 , p. 2, 1999.

[51] A. Krouska, C. Troussas, and M. Virvou, "A literature review of social networking- based learning systems using a novel ISO-based framework," Intelligent Decision Technologies, vol. 13, no. 1, pp. 23-39, 2019.

[52] United Nations, The Millennium Development Goals Report, UN, New York, NY, USA, 2010.

[53] J. W. Bentley, P. Van Mele, and G. Musimami, The Mud on Their Legs-Farmer-to-Farmer Videos in Uganda, Michigan 
State University, East Lansing, MI, USA, 2013, http://www. academia.edu.

[54] S. MacGregor, "Sustainability through vicarious learning: reframing consumer education," Social Learning Towards a Sustainable World, vol. 19, pp. 351-402, Wageningen Academic Publishers, Wageningen, Netherlands, 2007.

[55] C. Troussas, A. Krouska, and M. Virvou, "Using a multi module model for learning analytics to predict learners' cognitive states and provide tailored learning pathways and assessment," Machine Learning Paradigms, pp. 9-22, Springer, Berlin, Germany, 2020.

[56] KNEC, Kenya Certificate of Secondary Education Agriculture Syllabus, KNEC, Nairobi, Kenya, 2017, http://www.elimu.net/ secondary/kenya/kcse-student/agriculture.

[57] F. Annor-Frempong, M. Zinnah, and I. Adam, "Teaching of agricultural science at the basic education level in developing countries: a case study of the nature and constraints at Cape Coast district of Ghana," in Proceedings of the 19th Annual Conference, pp. 58-64, Raleigh, NC, USA, 2003.

[58] N. J. Kathuri, A study of the new agricultural education in the secondary school in Kenya, Ph.D. thesis, University of Illinois at Urbana, Champaign, IL, USA, 1990.

[59] UNESCO-UNEVOC, Participation in Formal Technical and Vocational Education and Training (TVET) Worldwide: An Initial Statistical Survey, UNESCO, Paris, France, http:// unevoc.unesco.org/fileadmin/user_upload/pubs/unevoc_uis_ report.pdf.

[60] IFPRI, Building Local Skills and Knowledge for Food Security, IFPRI, Washington, DC, USA, 2006, http://www.ifpri.org.

[61] B. Seevers and D. Graham, Education through Cooperative Extension, University of Arkansas Bookstore, Fayetteville, AR, USA, 3rd edition, 2012.

[62] IFAD-UNESCO, Assessing Methods to Teach Knowledge, Skills and Learning for Rural Youth, UNESCO, Paris, France, 2014.

[63] A. Kedir, S. Mohammed, and J. Kerime, "Food insecurity and agricultural shocks in the rural Ethiopia," Research Journal of Life Sciences, Bioinformatics, Pharmaceutical and Chemical Sciences, vol. 3, no. 2, pp. 175-188, 2017.

[64] P. Jagadeesan, "Factors affecting food security and contribution of modern technologies in food sustainability," Journal of the Science of Food and Agriculture, vol. 91, no. 15, pp. 2707-2714, 2017.

[65] J. W. Creswell and V. L. P. Clark, Designing and Conducting Mixed Methods Research, SAGE Publications, Thousand Oaks, CA, USA, 2011.

[66] N. Orion and A. Hofstein, "Factors that influence learning during a scientific field trip in a natural environment," Journal of Research in Science Teaching, vol. 31, no. 10, pp. 1097-1119, 1994.

[67] R. W. Borg and M. D. Gall, Educational Research: An Introduction, Longman Inc., New York, NY, USA, 1989.

[68] C. R. Kothari, Research Methodology: Methods and Techniques, New Age International Publishers, New Delhi, India, 2nd edition, 2011.

[69] P. Gill, K. Stewart, E. Treasure, and B. Chadwick, "Methods of data collection in qualitative research: interviews and focus groups," British Dental Journal, vol. 204, no. 6, pp. 291-295, 2008.

[70] O. M. Mugenda and A. G. Mugenda, Research Methods: Quantitative and Qualitative Approaches, Acts Press, Nairobi, Kenya, 2003.

[71] D. K. Kombo and D. L. Tromp, Proposal and Thesis Writing, Pauline's Publications Africa, Nairobi, Kenya, 2006.
[72] DFID, The Role of Relevant Basic Education in Achieving Food Security and Sustainable Rural Development, Emerging Market Group Limited, London, UK, 2005. 